\title{
Target Market Selection for the Major Aquaculture Products of Turkey - An Evaluation on Export Markets by Hybrid Multi-criteria Decision-making Approach
}

\author{
Pelin Çelik ${ }^{1, *}$ (D) Bilgen Akmermer ${ }^{1}$ (iD \\ ${ }^{1}$ Karadeniz Technical University, Faculty of Economics and Administrative Sciences, Trabzon, Turkey.
}

\section{How to cite}

Celik, P., Akmermer, B. (2022). Target Market Selection for the Major Aquaculture Products of Turkey - An Evaluation on Export Markets by Hybrid Multi-Criteria Decision-Making Approach. Aquaculture Studies, 22(1), AQUAST691. http://doi.org/10.4194/AQUAST691

\section{Article History}

Received 23 June 2021

Accepted 17 September 2021

First Online 27 September 2021

\section{Corresponding Author}

Tel.: +904623778786

E-mail: pcelik@ktu.edu.tr

\section{Keywords}

Fuzzy AHP

TOPSIS

Target market

Aquaculture

\begin{abstract}
After 50 years of rapid development, today's aquaculture industry has become one of the driving forces of economic growth in many countries thanks to the increasing aquaculture production. However, less attention has been given to its growing global market demand and its contribution to relevant countries' trade potential. Turkey has achieved significant success in aquaculture production dominated by Trout (oncorhynchus mykiss), Sea Bass (dicentrarchus labrax), and Sea Bream (dicentrarchus labrax) species thanks to its geographical and biodiversity advantages. Thereby, Turkey has an exporting advantage in the face of increasing global seafood consumption demand. In this paper, we focus on the target market selection of these priority products to support the exporting potential of Turkey. Therefore, this is a multicriterion problem, and this paper aims to provide forecasting about target markets based on qualitative and quantitative criteria by combining fuzzy analytic hierarchy process (FAHP) and the technique for order preference by similarity to ideal solution (TOPSIS) methods. Seven criteria as trade balance, consumption, distance, average tariff, ease of doing business, non-tariff requirement and logistics performance index were chosen for evaluating the target markets. According to FAHP results, the trade balance criterion has the most significant effect while the distance criterion has least effect on the decision problem for ranking the target countries. According to these seven criteria, Japan is the best target market for Trout and Sea Bass while Russian Federation is the best for Sea Bream.
\end{abstract}

\section{Introduction}

In the last 50 years, scientific researches have much improved the understanding of aquaculture industry (FAl), and global awareness for the need of managing the industry in a sustainable approach. However, although significant research and development studies have been developed for the industry mostly about supporting the ecosystem, less attention has been given to its remarkable economic contribution and growing market potential. It is quite noticeable that rapid population growth and urbanization, together with the growing awareness of nutrition, are increasing the importance of products and their demand worldwide. Therefore, the FAl really provides a continuous and high-return market advantage to potential countries. Thus, this study focuses on this blind side of the industry over Turkey which is one of the developing countries for the industry. In this part, for the beginning we discussed the industry both for global and Turkey, especially the growing consumption numbers and the important role of aquaculture production in meeting the demand. Then, we mentioned the aim of this study and the methodology with the literature review. In following parts, the methodology, application and results are submitted, and we concluded the study with discussion on results and future research suggestions. 


\section{The Growing Numbers for FAl and the Importance of Aquaculture Production}

The aquaculture industry is introduced by the United Nations Food and Agriculture Organization (FAO) as a rapidly developing and steadily growing sector compared to other agriculture industries. The significant secret behind this situation is the expected growth in the world population and increasing demand to the animal protein requirement for future nutrition. According to the UN, the world population will exceed 9 billion by 2050 and parallel to this numbers, demand for seafood consumption, due to the lack of any other nutritional equivalent and meet a significant part of the animal protein requirement nutrition, is also expected to increase in order to ensure adequate and balanced nutrition of societies. Today's global food fish ${ }^{1}$ consumption rate also supports this expectation. Global food fish consumption increased at an average annual rate of $3.1 \%$ from 1961 to 2017 , a rate almost twice that of annual world population growth (1.6\%) for the same period, and higher than all other animal protein foods (meat, dairy, milk, etc.) consumption which increased by $2.1 \%$ per year. The per capita food fish consumption increased from $9.0 \mathrm{~kg}$ (live weight equivalent) in 1961 to $20.5 \mathrm{~kg}$ in 2018 , by about $1.5 \%$ per year and is estimated to be $22 \mathrm{~kg}$ in 2025 (FAO, 2020). Considering the world population growth and per capita consumption, it is obvious that the market demand for seafood is increasing day by day. In order to meet this demand, world supply is carried out by capture aquaculture production (in inland and marine waters) and aquaculture production (in inland and marine waters) by related countries. However, because of the limited capture aquaculture production, the aquaculture production plays a key role in meeting the rising demand and now provides almost half of human consumption. The increasing contribution of seafood production to total production over the years is shown in Figure 1.

As shown in Figure 1, global fish ${ }^{2}$ production reached about 179 million tonnes, of which 82 million tonnes came from aquaculture production in 2018. 156 million tonnes of production were used for human consumption and 22 million tonnes were destined for non-food uses, mainly to produce fishmeal and fish oil. Based on the assumptions globally, total fish production is expected to expand to 204 million tonnes in 2030 (Cherry, 2020). Thus, it is expected that the contribution of aquaculture to global fish production will continue to grow and surpass total capture production by 2024 . By 2029, aquaculture production is projected to reach 105 million tonnes (OECD, 2020). This is a growing market for potential countries. According to trade statistics China alone provides $58.4 \%$ of the world's total production in 2018. India, Indonesia, Vietnam and Bangladesh follow China, respectively. The top ten producers produce
$89.8 \%$ of the world aquaculture production in 2018 (FAO, 2020).

\section{FAl in Turkey and the Aims of the Study}

$\mathrm{FAl}$, which is one of the leading industries for Turkey, has a significant importance in contributing to a wide range of employment opportunities and having a high trade potential. Turkey is surrounded by three seas and has many rivers, lakes, ponds, and reservoirs offering various opportunities in terms of capture and aquaculture production (TAGEM, 2019). Similar to other potential countries, while the capturing acuaculture production is showing a fluctuating exchange, aquaculture production tends to an increasing steadily thanks to its geographical advantages, advancing technologies and experienced human resources. In 2019, Turkey has reached to 628.631 tonnes in aquaculture production (TUIK, 2020) and achieved a significant success in three species: Rainbow Trout, Sea Bass, and Sea Bream. Turkey has become the leading country in Trout and Sea Bass production and the second country in Sea Bream production in Europe (Rad et al., 2021: 15). Thereby, Turkey has also an important advantage for exporting these products in the face of increasing global food consumption demand. However, in the current situation, Turkey has not yet shown its real potential for foreign trade sufficiently. In order to increase the exporting potential of these products and manage effective foreign trade policy, it is crucial to focus on target market selection and determine the primary target countries. In this context, this is one of the most important marketing decisions for exporting companies and foreign trade executives in any countries. However, we know that target market selection process is conducted by considering various criteria for every industry. Therefore, this is a multicriteria decision making (MCDM) problem and should be solved with related MCDM methods. In the line with this perspective, we determined the aims of this study as follows;

1. To determine the important criteria and their weights for target market selection and to create a decision support system for MCDM for FAI.

2. To provide forecasting to export executives about the priority target markets from 15 alternatives for each three aquaculture products (Trout, Sea Bass, and Sea Bream) for Turkey.

In order to achieve these aims; we discussed the methods in detail which we applied for both determining the criteria and ranking the countries for export within the MCDM methods in the methodology part supported by literature review.

\footnotetext{
${ }^{1}$ The term "food fish" refers to fish destined for human consumption, thus excluding fish for non-food uses.

"Unless otherwise specified, throughout this publication, the term "fish" indicates fish, crustaceans, molluscs and other aquatic animals, but excludes aquatic mammals, reptiles, seaweeds and other aquatic plants.
} 


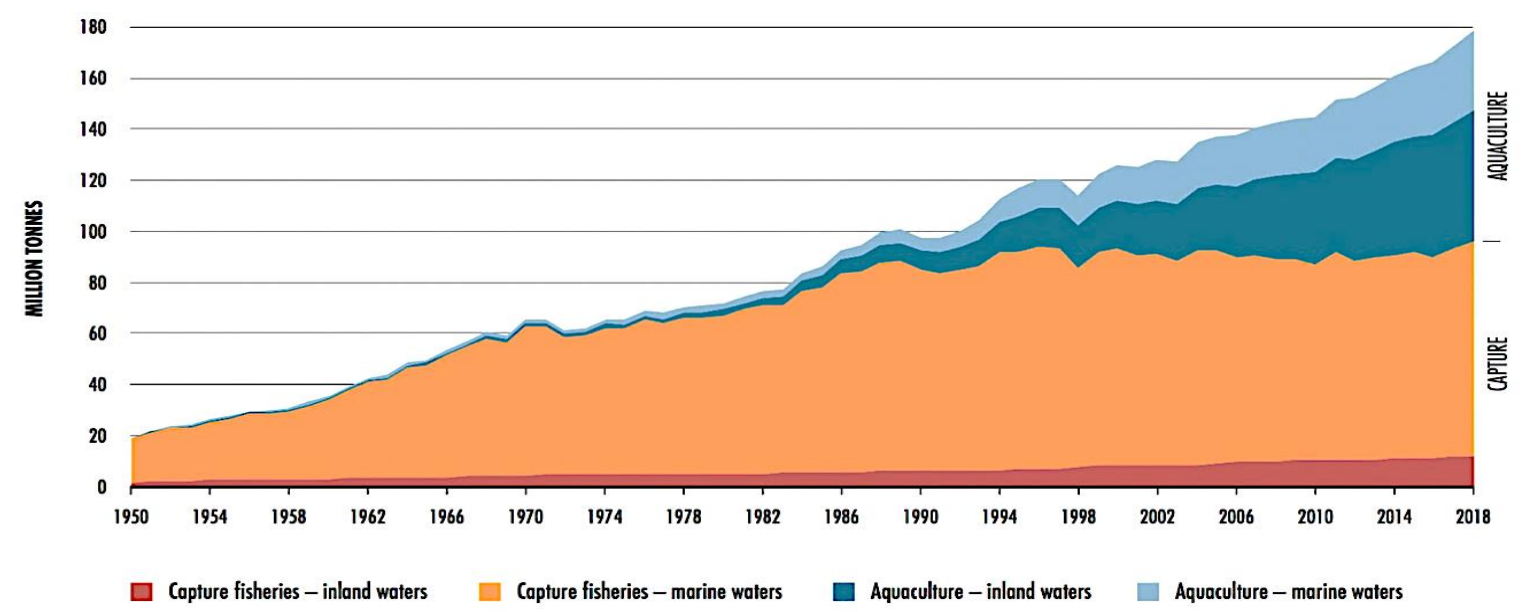

Figure 1. World Capture Fisheries and Aquaculture Production (Source: FAO, 2020)

\section{Material and Methods}

Multi-criteria decision making (MCDM) tools are used as a natural approach for evaluating alternatives with respect to conflict criterion, and target market selection can be considered as an MCDM problem (Aghdaie and Alimardani, 2015). Marketing literature highlights the importance of target market selection and also adopting data-driven approach by taking into consideration different MDCM methods that could be used in identifying target market for export. In recent years, numerous studies have been conducted to evaluate the selection of the target market for both organizations and industries with various MCDM methods. Albadvi et al. (2007) introduced the MCDM approach to rank alternative markets and determine the best target market with the PROMETHEE method for TV market in Iran. Aghdaie and Alimardani (2015) proposed a novel hybrid MCDM method including AHP and TOPSIS to elicit a suitable target market. Söyler and Yaraş (2016) also combined AHP and TOPSIS to select the target markets for travertine market. Yılmaz et al. (2017) focused on domestic target market selection for Turkish furniture industry by combining AHP and VIKOR. Ünal and Çetin (2019) also used AHP and TOPSIS method to determine 10 target countries for a fertilizer manufacturer operating in Turkey.

In this paper, we proposed a MCDM approach based on combination of fuzzy analytic hierarchy process (FAHP) and the technique for order preference by similarity to ideal solution (TOPSIS) methods for target market selection. FAHP was derived to select and calculate the criteria's weight and TOPSIS was applied to rank target market alternatives.

\section{Fuzzy Set Theory and Fuzzy AHP Method}

It is very difficult to make decisions in uncertain and blurred environmental conditions. It is possible to deal with this uncertainty with the fuzzy set theory proposed by Zadeh (1965) (Shaw et al., 2012: 8183). This feature makes it successful in most applications. Fuzzy set theory classifies objects according to membership degree (Javanbarg et al., 2012: 961).

The fuzzy set theory, which is different from the classical set theory, defines the realistic problem with the traditional mathematical value with the proposed membership degree (Ho, 2012: 955). In the literature, triangular and trapezoidal fuzzy numbers are used to reflect the uncertainty of subject-related parameters. In this study, triangular fuzzy numbers are used to express fuzzy relative importance. Triangular fuzzy numbers (TFN) can be defined as follows. A TFN, $\tilde{M}$ on $\mathrm{R}$ is provided by its membership function $\mu_{\tilde{M}}(x): U \subseteq R \rightarrow[0,1]$ which is linear piecewise continuous as (Kamvysi et al., 2014: 1087):

$$
\mu_{\tilde{M}}(x)= \begin{cases}\frac{x}{m-l}-, \frac{l}{m-l} & , x \in[l, m] \\ \frac{u}{u-m}-\frac{x}{u-m} & , x \in[m, u] \\ 0 & , \text { otherwise }\end{cases}
$$

If $M_{1}=\left(I_{1}, m_{1}, u_{1}\right)$ and $M_{2}=\left(I_{2}, m_{2}, u_{2}\right)$ and then the operational laws of addition, multiplication, reciprocal and division for these two TFN can be presented as follows:

$\mathrm{M}_{1} \oplus \mathrm{M}_{2}=\left(l_{1}, m_{1}, u_{1}\right) \oplus\left(I_{2}, m_{2}, u_{2}\right)=\left(l_{1}+l_{2}, m_{1}+m_{2}, u_{1}+u_{2}\right)$

$M_{1} \otimes M_{2}=\left(I_{1}, m_{1}, u_{1}\right) \otimes\left(I_{2}, m_{2}, u_{2}\right)=\left(I_{1} \times I_{2}, m_{1} \times m_{2}, u_{1} \times u_{2}\right)$

$\mathrm{M}_{1}^{-1}=\left(l_{1}, m_{1}, u_{1}\right)^{-1}=\left(1 / u_{1}, 1 / m_{1}, 1 / l_{1}\right)$

$\mathrm{M}_{1}(/) \mathrm{M}_{2}=\left(I_{1} / u_{2}, m_{1} / m_{2}, u_{1} / I_{2}\right)$

The fuzzy ratings and linguistic variables for the criteria are shown in Table 1. 


\section{Fuzzy AHP Method}

Analytic Hierarchy Process, first developed by Saaty in 1971, is a decision-making approach that aims to solve complex multi-criteria problems involving qualitative decisions (Calabrese vd., 2013: 2). The AHP is known as the most effective method used to solve complex decision-making problems, enabling decision makers to make binary comparisons between criteria (Chou vd., 2012: 71). AHP consists of two successive stages. The first stage is the design of the hierarchy that shows the relationship between decision elements such as the purpose of the decision problem, evaluation criteria and alternatives. The second stage is to evaluate the evaluation hierarchy, which consists of determining the weights of criteria and priorities of alternatives (Zheng, 2012: 229). The AHP allows decision makers to make binary comparisons between criteria and thus determine the criteria weights (Huang vd., 2008: 1041). In AHP, exact values such as 1-9 are used in determining the weights of the criteria according to each other. In fact, in most real cases, human evaluations are inaccurate and are ambiguous (Ishizaka ve Houng, 2013: 135). Fuzzy Analytical Hierarchy Process, which considers inconsistencies and uncertainties, has been developed to address these deficiencies (Javanbarg vd., 2012: 961). Although FAHP includes more complex calculations than AHP method, it is a method more suitable for the uncertain and complex thoughts of decision makers (Chaghooshi, 2012: 155).

In this study, Chang (1996)'s extended analysis is used to evaluate the weights of the criteria. Chang's extended analysis consists of the following steps (Chang, 1996: 649; Buyukozkan, Kahraman \& Ruan, 2004: 262; Eyüboğlu \& Çelik, 2016).

Step 1: By Equation (6), the values of fuzzy extensions for $i$-th object are calculated;

$$
S_{i}=\sum_{j=1}^{m} M_{g i}^{j} \otimes\left[\sum_{i=1}^{n} \sum_{j=1}^{m} M_{g i}^{j}\right]^{-1}
$$

In order to obtain the equation $\left[\sum_{i=1}^{n} \sum_{j=1}^{m} M_{g i}^{j}\right]^{-1}$, it is necessary to perform additional fuzzy operations with $m$ values of the extended analysis, which is represented in Equation (7) and (8);

$$
\begin{gathered}
\sum_{j=1}^{m} M_{g i}^{j}=\left(\sum_{j=1}^{m} l_{j}, \sum_{j=1}^{m} m_{j}, \sum_{j=1}^{m} u_{j}\right) \\
{\left[\sum_{i=1}^{n} \sum_{j=1}^{m} M_{g i}^{j}\right]=\left(\sum_{i=1}^{n} l_{i}, \sum_{i=1}^{n} m_{i}, \sum_{i=1}^{n} u_{i}\right)}
\end{gathered}
$$

The inverse vector is calculated by Equation (9)

$$
\left[\sum_{i=1}^{n} \sum_{j=1}^{m} M_{g i}^{j}\right]^{-1}=\left(\frac{1}{\sum_{i=1}^{n} u_{i}}, \frac{1}{\sum_{i=1}^{n} m_{i}}, \frac{1}{\sum_{i=1}^{n} l_{i}}\right)
$$

Step 2: The degree of possibility for $M_{2}$ is defined as:

$V\left(M_{2} \geq M_{1}\right)=\sup _{y \geq x}\left[\min \left(\mu_{M_{1}}(x), \mu_{M_{2}}(y)\right]\right.$

It can be represented in the following manner by Equation (12);

$$
\begin{aligned}
& V\left(M_{2} \geq M_{1}\right)=h g t\left(M_{2} \cap M_{1}\right) \mu M_{2}(d) \\
& =\left\{\begin{array}{cc}
1, \quad \text { if } & m_{2} \geq m_{1} \\
0, \quad \text { if } & l_{1} \geq u_{2} \\
\frac{l_{1}-u_{2}}{\left(m_{2}-u_{2}\right)-\left(m_{1}-l_{1}\right)}, & \text { otherwise }
\end{array}\right.
\end{aligned}
$$

where $d$ is the ordinate of the highest intersection point between $\mu M_{1}$ and $\mu M_{2}$. The values of $V\left(M_{2} \geq M_{1}\right)$ and $V\left(M_{1} \geq M_{2}\right)$ are needed to compare $\mu M_{1}$ and $\mu M_{2}$.

Step 3: Equation (13) defines the degree of possibility of fuzzy number $M_{i}(i=1,2, \ldots, \mathrm{k})$;

$$
\begin{aligned}
V(M & \left.\geq M_{1}, M_{2}, \ldots, M_{k}\right) \\
& =V\left[\left(M \geq M_{1}\right) i\left(M \geq M_{2}\right) i \ldots i\left(M \geq M_{k}\right)\right] \\
& =\min V\left(M \geq M_{i}\right), i=1,2,3, \ldots, k
\end{aligned}
$$

Table 1. Linguistic terms for criteria ratings

\begin{tabular}{lcc}
\hline Linguistic terms & Fuzzy numbers & Membership function \\
\hline Equally important & $\tilde{1}$ & $(1,1,3)$ \\
Less important & $\widetilde{3}$ & $(1,3,5)$ \\
Fairly important & $\widetilde{5}$ & $(3,5,7)$ \\
Important & $\tilde{7}$ & $(5,7,9)$ \\
Very important & $\tilde{9}$ & $(7,9,9)$ \\
\hline
\end{tabular}


Let assume that Equation (14);

$$
d^{\prime}\left(A_{i}\right)=\min V\left(S_{i} \geq S_{k}\right)
$$

for $k=1,2, \ldots, \mathrm{n} ; k \neq i$. By Equation (15), the weight vector is obtained as;

$$
W^{\prime}=\left(d^{\prime}\left(A_{1}\right), d^{\prime}\left(A_{2}\right), \ldots, d^{\prime}\left(A_{n}\right)\right)^{\top}
$$

where, $A_{i}(i=1,2, \ldots, n)$ consists of $n$ elements

Step 4: Through normalization, the weight vectors are reduced to Equation (16);

$$
W=\left(d\left(A_{1}\right), d\left(A_{2}\right), \ldots, d\left(A_{n}\right)\right)^{\top}
$$

where $\mathrm{W}$ represents a non-fuzzy number.

\section{TOPSIS Method}

TOPSIS was developed by Yoon and Hwang as a multi-criteria decision-making method in 1981 . TOPSIS method is defined as proximity to the positive ideal solution. Hwang and Yoon (1981) created the TOPSIS method according to the idea of the solution alternative, the shortest distance to the positive-ideal solution and the furthest distance to the negative-ideal solution. This idea was later applied by Zeleny (1982) and Hall (1989) and developed by Yoon (1987) and Hwang et al. (1993). TOPSIS method consists of the steps described below (Hwang and Yoon, 1981; Opricovic and Tzeng, 2004; Onut and Soner, 2007; Percin, 2009).

\section{Step 1: Creating the Decision Matrix (A)}

The rows of the matrix contain the decision points whose advantages are to be listed, and the columns contain the evaluation criteria to be used in decision making.

$$
\mathrm{A}=\left[\begin{array}{cccc}
a_{11} & a_{12} & \ldots & a_{1 n} \\
a_{21} & a_{22} & \ldots & a_{2 n} \\
\vdots & \vdots & \ldots & \vdots \\
a_{m 1} & a_{m 2} & \ldots & a_{m n}
\end{array}\right]
$$

Step 2: Normalizing the Decision Matrix (R)

In matrix $A, m$ is the number of alternatives and $n$ is the number of criteria. Using the elements of matrix A, normalized values are calculated using the formula below (Mahmoodzadeh, 2007: 400).

$$
r_{i j}=\frac{a_{i j}}{\sqrt{\sum_{k=1}^{m} a_{k j}^{2}}}
$$

Normalized Decision Matrix $(R)$ with $r_{i j}$ values is formed as follows.

$$
\mathrm{R}=\left[\begin{array}{cccc}
r_{11} & r_{12} & \ldots & r_{1 n} \\
r_{21} & r_{22} & \ldots & r_{2 n} \\
\vdots & \vdots & \ldots & \vdots \\
r_{m 1} & r_{m 2} & \ldots & r_{m n}
\end{array}\right]
$$

Step 3: Creating the Weighted Normalized Decision Matrix (V)

First, the weight values $\left(w_{i}\right)$ for the evaluation criteria are determined.

$$
\left(\sum_{i=1}^{n} w_{i}=1\right)
$$

Then, the elements in each column of the $\mathrm{R}$ matrix are multiplied by the corresponding value of wi and the $\mathrm{V}$ matrix is formed. The $\mathrm{V}$ matrix is shown below

$$
\mathrm{V}_{\mathrm{ij}}=\left[\begin{array}{cccc}
w_{1} r_{11} & w_{2} r_{12} & \ldots & w_{n} r_{1 n} \\
w_{1} r_{21} & w_{2} r_{22} & \ldots & w_{n} r_{1 n} \\
: & \vdots & \ldots & : \\
w_{1} r_{m 1} & w_{2} r_{m 2} & \ldots & w_{n} r_{m n}
\end{array}\right]
$$

Step 4: Determination of ideal $A^{*}$ and negative-ideal A solutions:

While the ideal solution consists of the best performance values of the weighted normalized decision matrix, the negative ideal solution consists of the worst values. In order to create the ideal solution set, the largest of the weighted evaluation factors, namely the column values, in the $\mathrm{V}$ matrix (the smallest if the relevant evaluation factor is minimized) is selected. Finding the ideal solution set is shown in the following equation.

$$
A^{*}=\left\{v_{1}^{*}, \ldots, v_{n}^{*}\right\}=\left\{\left(\max _{j} v_{i j} \mid i \in I^{\prime}\right),\left(\min _{j} v_{i j} \mid i \in I^{\prime \prime}\right)\right\}
$$

$$
A^{-}=\left\{v_{1}^{-}, \ldots, v_{n}^{-}\right\}=\left\{\left(\min _{j} v_{i j} \mid i \in I^{\prime}\right),\left(\max _{j} v_{i j} \mid i \in I^{\prime \prime}\right)\right\}
$$

Where I' means the value of the benefit and I" means the value of the cost.

Step 5: Determination of separation measurements by Euclidean distance approach:

$$
S_{i}^{*}=\sqrt{\sum_{i=1}^{n}\left(v_{i j}-v_{j}^{*}\right)^{2}}
$$

Likewise, measure of separation from the negative-ideal solution is obtained as: 


$$
S_{i}^{-}=\sqrt{\sum_{i=1}^{n}\left(v_{i j}-v_{j}^{-}\right)^{2}}
$$

Step 6: Computation of relative closeness to the ideal solution:

$$
C_{i}^{*}=\frac{S_{i}^{-}}{S_{i}^{-}+S_{i}^{*}}
$$

Step 7: Ranking the alternatives by priority.

\section{Results}

We took a stepwise approach from data collection to the evaluation of target markets.

\section{Data Collection Process}

We investigated the aquaculture production in detail and determined the most produced farmed products according to their average production amounts for the last 5 years. Trout, Sea Bass, and Sea Bream are by far the most produced species in aquaculture production of Turkey. Then, we examined the trade activities for these products to understand which types (fresh, frozen, preserved etc.) of products are subjected to trade activities. We predicated on the 6 digits of Harmonized Systems (HS) Codes of all types of products to calculate total trade data. Therefore, fresh, frozen, dried product types classified under "chapter 03 - Fish and crustaceans, molluscs and other aquatic invertebrates" and prepared-preserved product types classified under the "chapter 16 - Preparations of meat, of fish or crustaceans, molluscs or other aquatic invertebrates" were included to calculation. We created a product group for each product in TradeMap ${ }^{3}$ database and calculate all trade data according to these three product groups. We calculated the average data of the last five years (2015-2019) for each criterion Ultimately, a detail data collection process was implemented and all types of products which were subjected to foreign trade activities of Turkey, were included in all calculations.

\section{Criteria Selection Process}

In accordance with the purposes mentioned in this paper, we conducted a survey with the export experts, who have experiences in $\mathrm{FAl}$, to determine the primary criteria. They have regarded seven important criteria, defined below, for evaluating the alternative target markets for exporting the products of FAI. These criteria are;

Trade Balance (TB): TB is the difference between the monetary value of a nation's exports and imports value. While investigating an alternative country to import, trade balance value provides a meaningful information about the import potential of any country.

Consumption (C): Data is inclusive of all major seafood commodities, including all fisheries and aquaculture products. Consumption data show the per capita consumption amount in selected countries.

Distance (D): The geographic distance affects the cost of transportation. Therefore, for the companies engaged in the trade of solid products, the geographical segment is of great importance (Miloloza, 2015). Thus, we included distance criterion to the analyses. The distance corresponds to the average distance between the selected countries and Turkey. The data is derived from GEOBYTES data base.

Average tariff (estimated) faced by Turkey (\%) (AT): The tariff data is uniquely based on the minimum rates applied by the importing country(s).

Ease of Doing Business (ED): Economies are ranked on their ease of doing business, from 1 to 190 . The ranking of economies is determined by sorting the aggregate distance to frontier scores, rounded to two decimals. A high ease of doing business ranking means the regulatory environment is more conducive for doing business.

Non-tariff requirements faced by Turkey (NT): Nontariff barriers are trade barriers that restrict imports or exports of goods or services through mechanisms other than the simple imposition of tariffs.

Logistics Performance Index (LPI): LPI is an interactive benchmarking tool created to help countries identify the challenges and opportunities they face in their performance on trade logistics and what they can do to improve their performance. LPI is based on surveys that contain feedback from international operators on the countries in which they operate. Each country was scored from 5 (best) to 1 (bad) and published every 2 years (World Bank Group 2018).

\section{Determination of the Weights of Criteria Using FAHP}

The weights of the seven criteria are determined by Fuzzy AHP method. The pair wise comparison matrix is in Table 2.

After creating fuzzy pairwise comparison matrix, weights of 7 criteria are assessed by Fuzzy AHP. Synthetic values must be calculated, according to the Fuzzy AHP method. The synthetic values for each

\begin{tabular}{|c|c|c|c|c|c|}
\hline STD & $(11,21,31)$ & $\otimes$ & $(0.00703,0.01094,0.02110)$ & $=$ & $(0.08,0.23,0.65)$ \\
\hline $\mathrm{S}_{\mathrm{c}}$ & $(9.40,17.67,27)$ & Q & $(0.00703,0.01094,0.02110)$ & & $(0.07,0.19,0.57)$ \\
\hline $\mathrm{S}_{\mathrm{D}}$ & $(2.03,2.60,5)$ & $\otimes$ & $(0.00703,0.01094,0.02110)$ & $=$ & $(0.01,0.03,0.11)$ \\
\hline SAT & $(5.80,10.33,17)$ & & $(0.00703,0.01094,0.02110)$ & $=$ & $(0.04,0.11,0.36)$ \\
\hline SED & $(3.57,7.80,12.33)$ & & $(0.00703,0.01094,0.02110)$ & $=$ & $(0.03,0.09,0.26)$ \\
\hline VT & $(8.20,16.33,25.00)$ & 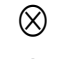 & $(0.00703,0.01094,0.02110)$ & 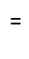 & $(0.06,0.18,0.53)$ \\
\hline & $(7.40,15.67,25.00)$ & & $(0.00703,0.01094,0.02110)$ & $=$ & $(0.05,0.17,0.53)$ \\
\hline
\end{tabular}
criterion are calculated by Equation (6); 
Table 2. Fuzzy pair wise comparison matrix

\begin{tabular}{|c|c|c|c|c|c|c|c|}
\hline & TB & $\mathrm{C}$ & $\mathrm{D}$ & AT & ED & NT & LPI \\
\hline TB & $(1,1,1)$ & $(1,3,5)$ & $(3,5,7)$ & $(1,3,5)$ & $(3,5,7)$ & $(1,1,1)$ & $(1,3,5)$ \\
\hline C & $(0.2,0.33,1)$ & $(1,1,1)$ & $(3,5,7)$ & $(1,3,5)$ & $(3,5,7)$ & $(1,3,5)$ & $(0.20,0.33,1)$ \\
\hline$D$ & $(0.14,0.20,0.33)$ & $(0.14,0.20,0.33)$ & $(1,1,1)$ & $(0.14,0.20,0.33)$ & $(0.20,0.33,1)$ & $(0.20,0.33,1)$ & $(0.20,0.33,1)$ \\
\hline AT & $(0.20,0.33,1)$ & $(0.20,0.33,1)$ & $(3,5,7)$ & $(1,1,1)$ & $(1,3,5)$ & $(0.20,0.33,1)$ & $(0.20,0.33,1)$ \\
\hline ED & $(0.14,0.20,0.33)$ & $(0.14,0.20,0.33)$ & $(1,3,5)$ & $(1,3,5)$ & $(1,1,1)$ & $(0.14,0.20,0.33)$ & $(0.14,0.20,0.33)$ \\
\hline NT & $(1,1,1)$ & $(0.20,0.33,1)$ & $(1,3,5)$ & $(1,3,5)$ & $(3,5,7)$ & $(1,1,1)$ & $(1,3,5)$ \\
\hline LPI & $(0.20,0.33,1)$ & $(1,3,5)$ & $(1,3,5)$ & $(1,3,5)$ & $(3,5,7)$ & $(0.20,0.33,1)$ & $(1,1,1)$ \\
\hline
\end{tabular}

Using Equation (13) and (14), the synthetic values are compared as;

\begin{tabular}{|c|c|c|c|c|c|c|c|}
\hline $\mathrm{V}\left(\mathrm{S}_{\mathrm{TD}} \geq \mathrm{S}_{\mathrm{C}}\right)$ & 1 & $\mathrm{~V}\left(\mathrm{~S}_{\mathrm{C}} \geq \mathrm{S}_{\mathrm{TD}}\right)$ & 0.931 & $\mathrm{~V}\left(\mathrm{~S}_{\mathrm{D}} \geq \mathrm{S}_{\mathrm{TD}}\right)$ & 0.123 & $V\left(S_{A T} \geq S_{T D}\right)$ & 0.7068 \\
\hline $\mathrm{V}\left(\mathrm{S}_{\mathrm{TD}} \geq \mathrm{S}_{\mathrm{D}}\right)$ & 1 & $\mathrm{~V}\left(\mathrm{~S}_{\mathrm{C}} \geq \mathrm{S}_{\mathrm{D}}\right)$ & 1 & $\mathrm{~V}\left(\mathrm{~S}_{\mathrm{D}} \geq \mathrm{S}_{\mathrm{C}}\right)$ & 0.193 & $V\left(S_{A T} \geq S_{C}\right)$ & 0.7848 \\
\hline$V\left(S_{T D} \geq S_{A T}\right)$ & 1 & $\mathrm{~V}\left(\mathrm{~S}_{\mathrm{C}} \geq \mathrm{S}_{\mathrm{AT}}\right)$ & 1 & $\mathrm{~V}\left(\mathrm{~S}_{\mathrm{D}} \geq \mathrm{S}_{\mathrm{AT}}\right)$ & 0.433 & $V\left(S_{A T} \geq S_{D}\right)$ & 1 \\
\hline $\mathrm{V}\left(\mathrm{S}_{\mathrm{TD}} \geq \mathrm{S}_{\mathrm{ED}}\right)$ & 1 & $\mathrm{~V}\left(\mathrm{~S}_{\mathrm{C}} \geq \mathrm{S}_{\mathrm{ED}}\right)$ & 1 & $\mathrm{~V}\left(\mathrm{~S}_{\mathrm{D}} \geq \mathrm{S}_{\mathrm{ED}}\right)$ & 0.586 & $V\left(S_{A T} \geq S_{E D}\right)$ & 1 \\
\hline $\mathrm{V}\left(\mathrm{S}_{\mathrm{TD}} \geq \mathrm{S}_{\mathrm{NT}}\right)$ & 1 & $\mathrm{~V}\left(\mathrm{~S}_{\mathrm{C}} \geq \mathrm{S}_{\mathrm{NT}}\right)$ & 1 & $V\left(S_{D} \geq S_{N T}\right)$ & 0.242 & $V\left(S_{A T} \geq S_{N T}\right)$ & 0.821 \\
\hline$V\left(S_{T D} \geq S_{L P I}\right)$ & 1 & $\mathrm{~V}\left(\mathrm{~S}_{\mathrm{C}} \geq \mathrm{S}_{\mathrm{LPI}}\right)$ & 1 & $\mathrm{~V}\left(\mathrm{~S}_{\mathrm{D}} \geq \mathrm{S}_{\mathrm{LPI}}\right)$ & 0.272 & $V\left(S_{A T} \geq S_{L P I}\right)$ & 0.8401 \\
\hline $\mathrm{V}\left(\mathrm{S}_{\mathrm{ED}} \geq \mathrm{S}_{\mathrm{TD}}\right)$ & 0.5588 & $\mathrm{~V}\left(\mathrm{~S}_{\mathrm{NT}} \geq \mathrm{S}_{\mathrm{TD}}\right)$ & 0.9 & $\mathrm{~V}\left(\mathrm{SL}_{\mathrm{PI}} \geq \mathrm{S}_{\mathrm{TD}}\right)$ & 0.88525 & & \\
\hline$V\left(S_{E D} \geq S_{C}\right)$ & 0.6427 & $\mathrm{~V}\left(\mathrm{~S}_{\mathrm{NT}} \geq \mathrm{S}_{\mathrm{C}}\right)$ & 0.97 & $V\left(S_{L P I} \geq S_{C}\right)$ & 0.95472 & & \\
\hline$V\left(S_{E D} \geq S_{D}\right)$ & 1 & $\mathrm{~V}\left(\mathrm{~S}_{\mathrm{NT}} \geq \mathrm{S}_{\mathrm{D}}\right)$ & 1 & $V\left(S_{L P I} \geq S_{D}\right)$ & 1 & & \\
\hline$V\left(S_{E D} \geq S_{A T}\right)$ & 0.8879 & $V\left(S_{N T} \geq S_{A T}\right)$ & 1 & $V\left(S_{L P I} \geq S_{A T}\right)$ & 1 & & \\
\hline$V\left(S_{E D} \geq S_{N T}\right)$ & 0.6845 & $V\left(S_{N T} \geq S_{E D}\right)$ & 1 & $V\left(S_{L P I} \geq S_{E D}\right)$ & 1 & & \\
\hline$V\left(S_{E D} \geq S_{L P I}\right)$ & 0.7075 & $V\left(S_{N T} \geq S_{L P 1}\right)$ & 1 & $V\left(S_{L P 1} \geq S_{N T}\right)$ & 0.98471 & & \\
\hline
\end{tabular}

Then the weights of the criteria are calculated as in Table 3.

The analysis shows that criteria TB, C, NT, and LPI are the primary criteria that affect the decision problem. Although, other criteria also important for the decision, criterion $D$ has the least and insignificant effect on the decision problem. However, all criteria are included in the analysis to suit the study objectives.

\section{Ranking the Alternative Target Countries by MCDM Method: TOPSIS}

We used TOPSIS to rank 15 potential target countries for each three aquaculture products using seven primary criteria that were weighted in the previous step. The countries, included in analysis, were selected among top importers of each product.

Firstly, we applied TOPSIS method to determine the target markets for Trout. The decision matrix is given in Table 4.

After applying the other steps of the TOPSIS method, we prioritized the target markets. The order of ranking from most primary country to the least is given in Table 5. The results show that according to the selected criteria, the most priority market for Trout is Japan. Other important export partners for Turkey are Germany and the United States.

Secondly, we applied TOPSIS method to Sea Bream to determine its target markets. The decision matrix for Sea Bream is seen in Table 6.

After applying the other steps of the TOPSIS method, we prioritized the target markets. The order of ranking from most primary country to the least is given in Table 7. The results show that according to the selected criteria, the Russian Federation is the priority market for Sea Bream much more than the other countries.
Lastly, all the TOPSIS method calculations are repeated for Sea Bass. Table 8 shows the decision matrix for Sea Bass.

After applying the other steps of the TOPSIS method, we prioritized the target markets. The order of ranking from most primary country to the least is given in Table 9. The results show that according to the selected criteria, Japan is also the priority market for Sea Bass. Other important export partners for Turkey are Finland and Saudi Arabia.

\section{Discussion}

Rapid population growth and urbanization, together with the growing awareness of nutrition and food security are expected to increase global seafood demand and so fisheries market. However, less attention has been given to its growing global market demand and its contribution to relevant countries' economic development. Turkey is one of the important countries for the industry with its geographic features, biodiversity, and trade potential to supply the demand in this growing market. Especially, aquaculture production in Turkey showed significant improvements in the last thirty years. Many important types of research have been carried out on increasing production and significant successes have been achieved in three species: Trout, Sea Bass, and Sea Bream. However, so limited studies were focused on their potential in global markets and growing contributions to Turkey's international trade. When examining researches in literature and sectoral reports about, it has seen that limited studies on economic perspective, just on supply chain, pricing and some basic market information, have been conducted in Turkey in the case of the seabream and seabass industry. Rad and Köksal (2008) presented the picture of the Turkish aquaculture sector, with further emphasis on biotechnical and economic aspects of its key areas of sea bass and sea bream production. Bjørndal et. al (2019) investigated whether Turkish exports of farmed Seabass affect prices of European Union (EU) farmed Seabass by examining the existence of market integration between the prices of Turkish exports of farmed Seabass into the EU and the prices of farmed European seabass commercialized in wholesale markets in Barcelona, Madrid and Paris. Llorente et. al. (2020), analyzed the economic performance of EU seabream and seabass companies in the period 20082016 as the first study to analyze companies' 
Table 3. Weights calculated by Fuzzy AHP

\begin{tabular}{lcccccc}
\hline TB & C & D & AT & ED & NT & 0.110 \\
\hline 0.197 & 0.183 & 0.019 & 0.139 & 0.177 & 0.174 & 0.13 \\
\hline
\end{tabular}

Table 4. Decision Matrix for Trout

\begin{tabular}{|c|c|c|c|c|c|c|c|}
\hline Top Importing Countries & TB & $\mathrm{C}$ & $\mathrm{D}$ & AT & ED & NT & LPI \\
\hline Japan & -427846.00 & 47.04 & 8527.30 & 3.5 & 29 & 10 & 4.004 \\
\hline Germany & -222904.20 & 13.20 & 2354.60 & 0 & 22 & 48 & 4.237 \\
\hline Russian Federation & -95104.20 & 21.24 & 5251.22 & 2.3 & 28 & 102 & 2.750 \\
\hline United States of America & -146810.40 & 21.90 & 10181.16 & 0 & 6 & 48 & 3.951 \\
\hline Saudi Arabia & -28978.60 & 12.56 & 1915.80 & 0 & 62 & 342 & 2.992 \\
\hline Poland & 16662.40 & 10.66 & 1902.51 & 0 & 40 & 48 & 3.478 \\
\hline Belarus & -65559.20 & 16.32 & 1730.27 & 2.3 & 49 & 2 & 2.473 \\
\hline Finland & -37658.60 & 34.49 & 2633.63 & 0 & 20 & 48 & 3.832 \\
\hline Sweden & 21218.00 & 33.34 & 2623.35 & 0 & 10 & 48 & 4.069 \\
\hline Thailand & -37484.00 & 25.32 & 6823.74 & 0 & 21 & 2 & 3.278 \\
\hline France & -35467.20 & 33.78 & 2798.73 & 0 & 32 & 48 & 3.803 \\
\hline Viet Nam & 4322.00 & 34.52 & 7572.99 & 10 & 70 & 52 & 3.125 \\
\hline Canada & -59296.40 & 22.58 & 8837.40 & 0 & 23 & 50 & 3.913 \\
\hline Romania & -18050.80 & 5.97 & 1144.14 & 0 & 55 & 48 & 3.029 \\
\hline Ukraine & -23129.80 & 12.20 & 1096.67 & 0 & 64 & 2 & 2.743 \\
\hline
\end{tabular}

Table 5. Scores for Trout

\begin{tabular}{lcccc}
\hline Rank & Countries & $S^{*}$ & $S^{-}$ & $C_{J}$ \\
\hline 1 & Japan & 0.048 & 0.256 & 0.842 \\
2 & Germany & 0.102 & 0.211 & 0.673 \\
3 & United States of America & 0.117 & 0.204 & 0.635 \\
4 & Thailand & 0.153 & 0.208 & 0.577 \\
5 & Finland & 0.150 & 0.198 & 0.569 \\
6 & Canada & 0.148 & 0.193 & 0.567 \\
7 & France & 0.152 & 0.196 & 0.563 \\
8 & Belarus & 0.155 & 0.188 & 0.548 \\
9 & Ukraine & 0.172 & 0.202 & 0.540 \\
10 & Sweden & 0.171 & 0.198 & 0.536 \\
11 & Russian Federation & 0.146 & 0.159 & 0.521 \\
12 & Romania & 0.178 & 0.186 & 0.511 \\
13 & Poland & 0.183 & 0.187 & 0.505 \\
14 & Viet Nam & 0.214 & 0.144 & 0.402 \\
15 & Saudi Arabia & 0.230 & 0.128 & 0.358 \\
\hline
\end{tabular}

Table 6. Decision Matrix for Sea Bream

\begin{tabular}{|c|c|c|c|c|c|c|c|}
\hline Top Importing Countries & TB & $\mathrm{C}$ & $\mathrm{D}$ & AT & ED & NT & $\mathrm{LPI}$ \\
\hline China & 1408714.80 & 36.80 & 5949.59 & 10 & 31 & 92 & 3.557 \\
\hline Korea & -609789.80 & 54.54 & 7789.73 & 20 & 5 & 3 & 3.648 \\
\hline Japan & -1219616.20 & 47.04 & 8527.30 & 3.5 & 29 & 10 & 4.004 \\
\hline United States of America & -127857.40 & 21.90 & 10181.16 & 0 & 6 & 48 & 3.951 \\
\hline Philippines & -21921.60 & 29.56 & 8814.93 & 10 & 90 & 1 & 2.805 \\
\hline Thailand & -72497.80 & 25.32 & 6823.74 & 0 & 21 & 2 & 3.278 \\
\hline Côte d'Ivoire & -74835.80 & 17.35 & 5362.98 & 10 & 110 & 1 & 2.824 \\
\hline Italy & -409266.80 & 28.45 & 1940.74 & 0 & 58 & 48 & 3.683 \\
\hline France & -470227.60 & 33.78 & 2798.73 & 0 & 32 & 48 & 3.803 \\
\hline Malaysia & -62084.60 & 57.90 & 7712.15 & 0 & 12 & 19 & 3.369 \\
\hline Taiwan & 95591.80 & 31.92 & 8026.49 & 15 & 15 & 2 & 3.673 \\
\hline Russian Federation & -80062.40 & 21.24 & 5251.22 & 2.3 & 28 & 102 & 2.750 \\
\hline Spain & -101266.80 & 42.99 & 3312.08 & 0 & 30 & 48 & 3.786 \\
\hline Germany & -236307.20 & 13.20 & 2354.60 & 0 & 22 & 48 & 4.237 \\
\hline Senegal & 76772.60 & 19.72 & 5546.20 & 10 & 95 & 1 & 2.343 \\
\hline
\end{tabular}


Table 7. Scores for Sea Bream

\begin{tabular}{lcccc}
\hline Rank & Countries & $\mathrm{S}^{*}$ & $\mathrm{~S}^{-}$ & $\mathrm{C}_{\mathrm{J}}$ \\
\hline 1 & Russian Federation & 0,029 & 0,187 & 0,866 \\
2 & Sweden & 0,093 & 0,133 & 0,588 \\
3 & Germany & 0,108 & 0,150 & 0,581 \\
4 & Thailand & 0,112 & 0,153 & 0,578 \\
5 & Poland & 0,119 & 0,149 & 0,558 \\
6 & Finland & 0,105 & 0,124 & 0,542 \\
7 & Canada & 0,119 & 0,128 & 0,518 \\
8 & United States of America & 0,124 & 0,129 & 0,510 \\
9 & Romania & 0,122 & 0,127 & 0,510 \\
10 & France & 0,147 & 0,124 & 0,458 \\
11 & Saudi Arabia & 0,141 & 0,115 & 0,450 \\
12 & Belarus & 0,148 & 0,113 & 0,433 \\
13 & Ukraine & 0,154 & 0,112 & 0,421 \\
14 & Viet Nam & 0,159 & 0,098 & 0,382 \\
\hline
\end{tabular}

Table 8. Decision Matrix for Sea Bass

\begin{tabular}{|c|c|c|c|c|c|c|c|}
\hline Top Importing Countries & TB & C & $\mathrm{D}$ & AT & ED & NT & LPI \\
\hline Japan & -979017.60 & 47.04 & 8527.30 & 3.5 & 29 & 10 & 4.004 \\
\hline Korea, Republic of & -280096.60 & 54.54 & 7789.73 & 20 & 5 & 3 & 3.648 \\
\hline China & 1094866.80 & 36.80 & 5949.59 & 10 & 31 & 92 & 3.557 \\
\hline Thailand & 27159.00 & 25.32 & 6823.74 & 0 & 21 & 2 & 3.278 \\
\hline France & -351000.00 & 33.78 & 2798.73 & 0 & 32 & 48 & 3.803 \\
\hline Poland & -15682.60 & 10.66 & 1902.51 & 0 & 40 & 48 & 3.478 \\
\hline Germany & -210829.40 & 13.20 & 2354.60 & 0 & 22 & 48 & 4.237 \\
\hline Hong Kong, China & -245858.80 & 70.64 & 7534.73 & 0 & 3 & 14 & 3.913 \\
\hline Taiwan & 146941.40 & 31.92 & 8026.49 & 15 & 15 & 2 & 3.673 \\
\hline Russian Federation & -32916.60 & 21.24 & 5251.22 & 2.3 & 28 & 102 & 2.750 \\
\hline Italy & -191280.20 & 28.45 & 1940.74 & 0 & 58 & 48 & 3.683 \\
\hline Philippines & 36492.20 & 29.56 & 8814.93 & 10 & 90 & 1 & 2.805 \\
\hline Malaysia & -18779.80 & 57.90 & 7712.15 & 0 & 12 & 19 & 3.369 \\
\hline Saudi Arabia & -21951.60 & 12.56 & 1915.80 & 0 & 62 & 342 & 2.992 \\
\hline Netherlands & 30246.20 & 21.90 & 2724.19 & 0 & 42 & 48 & 4.144 \\
\hline
\end{tabular}

Table 9. Scores for Sea Bass

\begin{tabular}{lcccc}
\hline Rank & Countries & $S^{*}$ & $S^{-}$ & $C_{J}$ \\
\hline 1 & Japan & 0.040 & 0.317 & 0.887 \\
2 & Finland & 0.091 & 0.265 & 0.744 \\
3 & Saudi Arabia & 0.096 & 0.251 & 0.722 \\
4 & Canada & 0.121 & 0.241 & 0.665 \\
5 & Belarus & 0.123 & 0.239 & 0.659 \\
6 & France & 0.121 & 0.233 & 0.658 \\
7 & Germany & 0.131 & 0.247 & 0.653 \\
8 & United States of America & 0.139 & 0.234 & 0.627 \\
9 & Ukraine & 0.145 & 0.217 & 0.600 \\
10 & Poland & 0.147 & 0.220 & 0.599 \\
11 & Thailand & 0.144 & 0.204 & 0.585 \\
12 & Viet Nam & 0.160 & 0.212 & 0.571 \\
13 & Sweden & 0.165 & 0.208 & 0.557 \\
14 & Romania & 0.217 & 0.170 & 0.440 \\
15 & Russian Federation & 0.269 & 0.138 & 0.338 \\
\hline
\end{tabular}


profitability in the EU as a whole, by country and company size, using economic and financial data extracted from companies' annual accounts. In 2021, "Sea Bass and Sea Bream Supply Chain Study: From Turkey to Europe. Fish Forward Project and Report" was prepared by Mersin University (Turkish component) and MacAlister Elliott and Partners Ltd (the UK and Austrian component) in collaboration with WWF to provide a comprehensive snapshot of the supply chain for Turkish exports to Europe (Rad et. al, 2021). As can be seen, economic studies have started to gain importance in recent years. However, none of these important studies have been focused on the issues for providing forecasting about potential markets of these products. This is an important issue for Turkey both to improve its exporting capacity and to build a sustainable income channel for the industry. Thus, we focus on determining potential markets of related products for Turkey by qualitive and quantitative perspectives.

We know that target market selection is a multicriterion problem and should be evaluated by both qualitative and quantitative criteria. Thus, we combined FAHP and TOPSIS method to evaluate and rank fifteen potential countries for each product. In the first step of the analysis, we conducted a survey with the export experts to determine the primary criteria. Seven criteria as trade balance, distance, consumption, average tariff, ease of doing business, non-tariff requirement and logistics performance index were chosen for creating a decision support system for FAI. In the second step, fuzzy AHP method is applied for the determination of the weights of these criteria. Trade balance (0.197) is found as the most important criterion, followed by consumption (0.183) and non-tariff requirement (0.177) while distance $(0,019)$ has the least effect on the decision for ranking the target countries. According to the results, we found a unique result. Distance criterion which is important for export executives in many industries is not a prior criterion for the aquaculture industry. In the third step, TOPSIS method is applied to evaluate the fifteen alternative countries for each three aquaculture products. According to the results, Japan is the best target country for Trout followed by Germany and the United States of America. Russian Federation, Sweden, and Germany are found as the top three countries for Sea Bream. Japan, Finland and Saudi Arabia are determined as the top three countries for Sea Bass. The exporting companies should consolidate the trade relations with these top three target countries. However, the first ten countries may also be considered as potential target markets for the companies according to companies' own sources and trade opportunities.

\section{Conclusion}

In conclusion, we think that the findings of this study will contribute towards providing important and advanced knowledge by various criteria and a simple, efficient method for foreign trade executives and exporting companies to increase their ability to choose an appropriate target country for the three main aquaculture products of Turkey. This study will also contribute to improve the exporting capacity of Turkey and build a sustainable income channel for the industry in the long term. We also expect to contribute to enterprises to gain new insights and impacts, especially for the awareness on managing the industry in a sustainable manner by focusing on its economic contribution side. For future research, similar analyses can be repeated using different criteria for various potential FAl products and countries.

\section{Ethical Statement}

This study does not require ethical statement.

\section{Funding Information}

No funding information is available.

\section{Author Contribution}

BA: Conceptualization, writing- original draft, data collection; PC: conceptualization, writing- original draft and editing, data analysis and visualization. PC and BA have designed the paper structure and contributed to editing and revising the article. All authors read and approved the final manuscript.

\section{Conflict of Interest}

The authors declare that they have no known competing financial or non-financial, professional, or personal conflicts that could have appeared to influence the work reported in this paper.

\section{Acknowledgements}

This paper does not contain any
acknowledgements.

\section{References}

Albadvi , A., Sharifi, S.A.R. and Qahri-Saremi, S., (2007). Application of "PROMETHEE" for market targeting: A case study on the TV market in Iran, Scientia Iranica 14(3), 221-229.

Aghdaie, M.H. and Alimardani M., (2015). "Target market selection based on market segment evaluation: A multiple attribute decision making approach", International Journal of Operational Research, 24(3):262-278.

Büyüközkan, G., Kahraman, C., \& Ruan, D. (2004). A fuzzy multi-criteria decision approach for software development strategy selection. International Journal of General Systems, 33, 259-280.

Calabrese, A., Costa, R., Menichini, T. (2013), “Using Fuzzy AHP to Manage Intellectual Capital Assets: An Application to the ICT Service Industry", Expert Systems with Applications, 40 (9), 3447-3755. 
Chaghooshi, A.J., Safari, H., Fathi, M.R. (2012), "Integration of Fuzzy AHP and Fuzzy GTMA for Location Selection of Gas Pressure Reducing Stations: A Case Study", Journal of Management Research, 4 (3), 152-169

Chang, D.Y. (1996). Applications of the extent analysis method on Fuzzy AHP. European Journal of Operational Research. 95, 649-655.

Cherry, D. (2020), "UN: Global aquaculture production continues to smash records", https://www.intrafish.com/trade/un-global-

aquaculture-production-continues-to-smash-records/21-821895

Chou, Y-C., Sun, C-C., Yen, H-Y. (2012), "Evaluating the Criteria for Human Resource for Science and Technology (HRST) Based on an Integrated Fuzzy AHP and Fuzzy Dematel Approach", Applied Soft Computing, 12, 64-71.

Eyüboğlu, K. and Çelik, P. (2016). Financial Performance Evaluation of Turkish Energy Companies with Fuzzy AHP and Fuzzy TOPSIS Methods, Business and Economics Research Journal, 7, 21-37.

FAO (2020), http://www.fao.org/fishery/statistics/software/fi shstatj/en

Gaston-Breton, Ch., \& Martin, O. M. (2011). International market selection andsegmentation: a two-stage model. International Marketing Review, 28(3), 267-290. http://dx.doi.org/10.1108/02651331111132857

GEOBYTES data base (2020), "Geographical distance of countries", https://geobytes.com/

Ho, C.C. (2012), "Construct Factor Evaluation Model of Health Management Center Selected By Customers With Fuzzy Analytic Hierarchy Process", Expert Systems with Applications, 39, 954-959.

Huang, C.C., Chu, P.-Y., Chiang, Y.H. (2008) “A Fuzzy AHP Application in Government-Sponsored R\&D Project Selection" Omega, 36(6), 1038-1052.

Hwang, C.L., \& Yoon, K. (1981). Multiple attributes decision making methods and applications. Berlin: Springer.

Ishizaka, A., Hoang, N. (2013), "Calibrated Fuzzy AHP for Current Bank Account Selection", Expert Systems with Applications, 40 (9), 3775-3783.

Javanbarg, M.B., Scawthorn, C., Kiyono, J., Shahbodaghkhan, B. (2012), "Fuzzy AHP-Based Multicriteria Decision Making Systems Using Particle Swarm Optimization", Expert Systems with Applications, 39, 960-966.

Kamvysi K., Gotzamani, K., Andronikidis, A. \& Georgiou, A.C. (2014). Capturing and prioritizing students' requirements for course design by embedding FuzzyAHP and linear programming in QFD. European Journal of Operational Research, 237, 1083-1094.

Mahmoodzadeh, S., Shahrabi, J., Pariazar, M., Zaeri, M.S. (2007), "Project Selection by Using Fuzzy AHP and TOPSIS Technique", International Journal of Humanities and Social Sciences, 1 (3), 135-140.

Miloloza, H. (2015). Distance Factors and Croatian Export Obstacles in the EU15: Cage Approach, Interdisciplinary Description of Complex Systems 13(3), 434-449.

OECD, 2020, OECD Agriculture Statistics, https://www.oecdilibrary.org/agriculture-and-food/data/oecdagriculture-statistics_agr-data-en

Onut, S. \& E. Soner (2007). Transshipment Site Selection Using The AHP and TOPSIS Approaches Under Fuzzy
Environment. Waste Management 28, 1552-1559.

Opricovic, S. \& G.H. Tzeng (2004). Compromise Solution by MCDM Methods: A Comparative Analysis of VIKOR and TOPSIS", European Journal of Operational Research 156, 445-455.

Percin, S. (2009). Evaluation Of Third-Party Logistics (3PL) Providers by Using a Two Phase AHP and TOPSIS Methodology. Benchmarking: An International Journal, 16(5), 588-604.

Rad, F. \& Köksal, G. (2000). "An overview of aquaculture in Turkey: With emphasis on sea bass and sea bream", Aquaculture Economics \& Management, 4:3-4, 227-239.

Rad, F., Goulden, M., Aytemiz, T., Gürgen, E., and Serpin, N. (2021), "WWF, 2021. Sea bass and sea bream supply chain study: from Turkey to Europe. Fish Forward Project: Responsible seafood consumption for the benefit of people, oceans and climate. Published by WWF-UK." Technical Report,

https://wwfint.awsassets.panda.org/downloads/wwf_fi shforwardprojectsbsb_2021_v5.pdf

Rao, R.V. (2008), "Evaluating Flexible Manufacturing Systems Using A Combined Multiple Attribute Decision Making Method" International Journal of Production Research, 46 (7), 1975-1989.

Shaw, K., Shankar, R., Yadav, S.S., Thakur, L.S. (2012), "Supplier Selection Using Fuzzy AHP and Fuzzy Multi-Objective Linear Programming For Developing Low Carbon Supply Chain", Expert Systems with Applications, 39, 8182-8192

Söyler H, Yaraş, E. (2016). Küresel Pazara Giriş Kararının Bulanık AHP Ve Bulanık TOPSIS Yaklaşımıyla Analizi. Manas Sosyal Araştırmalar Dergisi 5(4): 77-96.

TAGEM (2019), General Directorate of Agricultural Research and Policy,

https://www.tarimorman.gov.tr/TAGEM/Belgeler/yayin /Su\%20Ürünleri\%20Sektör\%20Politika\%20Belgesi\%202 019-2023.pdf.

TRADEMAP (2015) Trade statistics for international business development. http://www.trademap.org/Index.aspx

Bjørndal, A., Guillen, J. and Rad. F.(2019), "Are farmed European seabass (Dicentrarchus labrax) prices in European Union markets affected by Turkish exports of farmed European seabass?", Aquaculture Economics \& Management, 23(3), 341-357.

TUIK, (2020), Fisheries and Aquaculture Statistics. Retrieved on December 2, 2020 from http://www.tuik.gov.tr

Ünal Zeynep, Ipekci Cetin, Emre. (2019), “Gübre Üreticisinin Hedef Pazar Seçiminde Bütünleşik AHP-TOPSIS Yöntemi, Mediterranean Agricultural Sciences, 32(3):357-364.

World Bank Group (2020) Indicators database. https://lpi.worldbank.org/about

World Bank Group (2018). Global Rankings 2018. https://lpi.worldbank.org/international/global/2018.

Yılmaz, K., Öztürk, Y., \& Burdurlu, E. (2017). Target market selection for furniture companies with the multiple criteria decision-making approach. Journal of Advanced Technology Sciences, 6(3), 744-756.

Zheng, G., Zhu, N., Tian, Z., Chen, Y., Sun, B. (2012), "Application of A Trapezoidal Fuzzy AHP Method for Work Safety Evaluation and Early Warning Rating of Hot and Humid Environments", Safety Science, 50, 228-239. 